\title{
THE IMPACT OF LOCKDOWN DUE TO COVID-19 IN 2020 ON READING HABITS OF ACADEMIC STAFF OF STATE OPEN UNIVERSITIES: A STUDY
}

\author{
Dr. Priyanki Vyas \\ Mr. Balvant Tandel
}

\begin{abstract}
The study is based on theoretical aspects of reading habits. The understanding derived from this investigation contributes to practical issues relating to reading habits during lockdown due to COVID-19 epidemic in 2020. The population of the research is the faculties of the open state universities of India. The sample of the study is the faculties of Dr. Babasaheb Ambedkar Open University, located in Ahmedabad city under Gujarat state of the Republic of India. The important findings that arise from this study covers regarding, frequency of reading and reading materials, source of reading, style of reading, reasons of reading, time spent for reading before and during the lockdown etc. The researcher has analysed demographic and frequency through tabulation, percentage and simple average. This study is useful for faculty members, professionals, and students etc. of library and information science.
\end{abstract}

Keywords: Reading habits, Lockdown, COVID-19, Dr. Babasaheb Ambedkar Open University, Academic staff, State Open University 


\section{Introduction}

The study focuses on the reading habits of the academic staff of Dr Babasaheb Ambedkar Open University during the lockdown of COVID-19 in 2020 when the whole of India is lockdown due to the epidemic of coronavirus. People all over the country spend their time at home. Activities like sitting at home, doing home/household work, talking on the phone, watching television and screens, writing, and reading etc. to pass the time.

The traditional reading patterns of readers have not changed with the influence of the Internet and electronic media. Nevertheless, reading habits, whether using modern patterns or traditional patterns, which play an important role in improving readers' performance.

Reading people aims to teach you how to evaluate people's complex characteristics and how to see the overall pattern of those characteristics from- the pattern that truly can reveal and predict behaviour (Dimitrius, 1999).

In this study, the researcher has conducted a survey on the impact on the reading habits of the academic staff of $\mathrm{Dr}$ Babasaheb Ambedkar Open University (BAOU) during the lockdown of COVID-19 in 2020.

\section{Literature Review}

Theoretical aspects of reading habits

(Karim, 2007) Found that, the web site is seen as an increasingly important reading source. They observed some differences in reading habits and attitudes were between male and female.

(Annable, 2017) In this report, she found it included: knowledge is power, perceived reading ability determines the extent to which an adult engages in the reading process, early support systems in reading development influence us lifelong, and no matter a person's age, a purpose for reading is necessary.

(Mikulecky, Shanklin, \& Caverly, 1979) Found that the fully employed women, they do significantly more job-related reading than do fully employed males. He also found the reading attitude was high among retirees, housewives, and the unemployed who faced no required reading. 
Towards Excellence: An Indexed, Refereed \& Peer Reviewed Journal of Higher Education / Dr. Priyanki Vyas \& Mr. Balvant Tandel/ Page 28-37

(Chettri \& Rout, 2013) explained that, the importance of reading habits and various factors influencing reading habits, also described the role of ICT promoting reading habits.

\section{Objectives}

- To study the reading habits of Academic Staff

- To know the frequency of the reading materials

- To understand whether the Academic Staff spend time reading during the lockdown

- To analyse the reading habits before and during the lockdown

\section{Methodology}

Data collection: This research work is based on survey methods. Data has been collected from primary and secondary sources. Primary data is collected from responses of Academic Staff to structure the questionnaire. The secondary data is collected from books, reports, journals. Population: The target population was only for Academic Staff of BAOU. The present study is limited to the only for Academic Staff from BAOU. There were 29 teaching members from four different schools, namely School of Humanities \& Social Sciences, School of Commerce and Management, School of Computer Science, and School of Education, Distance Education and Education Technology. Sampling techniques: Researcher has selected using convenient sampling method and respondents were selected using simple random sampling.

Sample size: The sample size selected for the study included 29 teaching members from four different schools.

Statistical tools: the tools for analysis of data are tabular based on frequency, percentage and simple averages.

\section{Analysis}

Demographic Analysis

In this demographic analysis Table, 1 shows that the gender and age group of respondents. In this data maximum respondents were female (55\%), followed by males (45\%).

Table 1: Gender and age-wise distribution

Aspect of Frequency Percentage

May, 2020. VOL.12. ISSUE NO. 1 https://hrdc.gujaratuniversity.ac.in/Publication $\quad$ Page | 30 


\begin{tabular}{lcc}
\hline Demography & & \\
\hline Gender & & \\
Male & 13 & 45 \\
Female & 16 & 55 \\
Total & $\mathbf{2 9}$ & $\mathbf{1 0 0}$ \\
Age group & & \\
21 to 30 & 06 & 21 \\
31 to 40 & 14 & 48 \\
41 to 50 & 10 & 34 \\
50 above & - & - \\
Total & $\mathbf{2 9}$ & $\mathbf{1 0 0}$ \\
\hline
\end{tabular}

The distribution of age group also depicts the maximum respondents were from the age group 31 to 40 is $48 \%$, followed by the age group 41 to 50 is $34 \%$.

Reading habits

In this study, also analysis the reading habits of respondents. Here Table 2 and chart 1 shows enjoy reading during the lockdown that, a majority of respondents were given the response 'yes' that is $79 \%$, followed by respondents given their opinion about reading 'No' is $17 \%$.

Table 2: Enjoy reading during lockdown

\begin{tabular}{lcc}
\hline Response & Frequency & Percentage \\
\hline Yes & 23 & 79 \\
No & 05 & 17 \\
Can't say & 01 & 4 \\
Total & $\mathbf{2 9}$ & $\mathbf{1 0 0}$ \\
\hline
\end{tabular}

Chart 1: Enjoy reading during lockdown

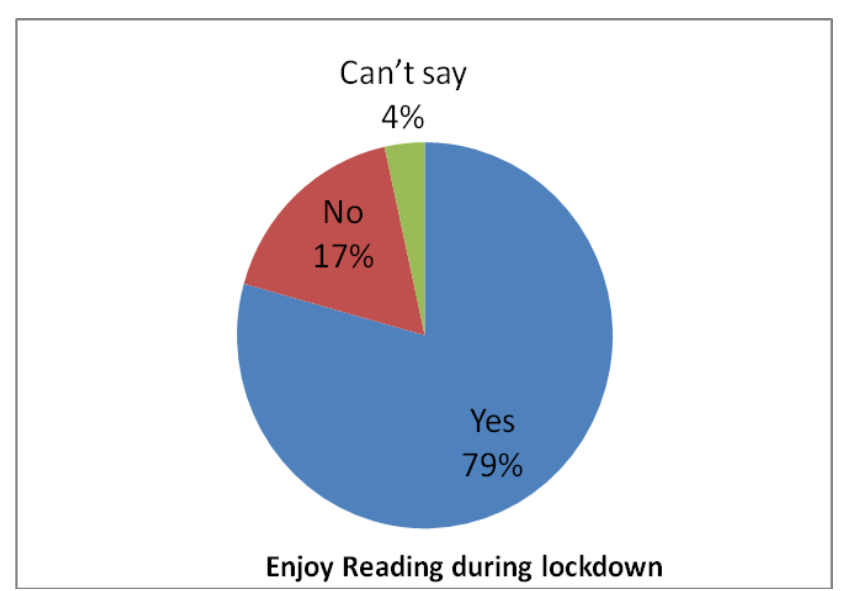

Academic staff was reading frequently during the lockdown. In table 3, data shows that the most of respondents were reading 'everyday' is $83 \%$, followed by some of the respondents are reading 'sometimes' that is $14 \%$. 
Table 3: Frequently reading

\begin{tabular}{lcc}
\hline & Frequency & Percentage \\
\hline Everyday & 24 & 83 \\
Occasionally & 01 & 3 \\
Sometimes & 04 & 14 \\
Total & $\mathbf{2 9}$ & $\mathbf{1 0 0}$ \\
\hline
\end{tabular}

Type of sources they are preferred for reading i.e. print, electronics and both the forms.

Table 4 reveals that most of the respondents were using 'both' the sources are $76 \%$, followed by some of the respondents were reading 'electronic source' is $17 \%$.

Source of Reading

Table 4: Types of source reading during lockdown

\begin{tabular}{lcc}
\hline Source & Frequency & Percentage \\
\hline Print & 02 & 7 \\
Electronics & 05 & 17 \\
Both & 22 & 76 \\
Total & $\mathbf{2 9}$ & $\mathbf{1 0 0}$ \\
\hline
\end{tabular}

Different sources to seek the information by academic staff. In table 5 presents that, the mean range from 2.00 to 0.20 , the priority given by respondents for 'books', followed by 'audio-visual' source is the second priority of the respondents. In this data, there were very least priority given for 'textbook'.

Sources to seek information

Table 5: use of source to seek information

\begin{tabular}{lccc}
\hline Sources & $\mathrm{N}$ & Mean & Priority \\
\hline Books & 28 & 2.00 & 1 \\
Audio-visual & 28 & 1.80 & 2 \\
Newspapers & 28 & 1.20 & 3 \\
Jour. \& & 28 & & 4 \\
magazines & & 0.40 & \\
Textbooks & 28 & 0.20 & 5 \\
\hline
\end{tabular}

The reading materials that use to update their subject knowledge are i.e. reference books, journals, newspapers, textbooks, magazines, and others. In table 6 shows that, the mean range given from 3.40 to 0.20 , most priority given for the 'reference book' mean is 3.40 followed that, 'other sources' and 'journals' mean is 1.00 and 0.60 respectively. The least priority given by the respondents for the 'newspapers', 'textbooks', and 'magazines' mean is 0.20 respectively.

\section{Update subject knowledge}

Table 6: Reading materials use to update subject knowledge

\begin{tabular}{lccc}
\hline $\begin{array}{l}\text { Reading } \\
\text { Materials }\end{array}$ & N & Mean & $\begin{array}{c}\text { Priorit } \\
y\end{array}$ \\
\hline Ref. Books & 28 & 3.40 & 1 \\
Other sources & 28 & 1.00 & 2 \\
Journals & 28 & 0.60 & 3
\end{tabular}




\begin{tabular}{lllc} 
Newspapers & 28 & 0.20 & 4 \\
Textbooks & 28 & 0.20 & 4 \\
Magazines & 28 & 0.20 & 4 \\
\hline
\end{tabular}

People are reading newspaper and getting and updating of knowledge. In this study teaching members are reading newspaper before and during the lockdown period. In table 7 shows that most of the respondents 'everyday' reading newspapers before and during lockdown respectively is $52 \%$ and $45 \%$., followed that 'sometimes' reading before and during this situation is $31 \%$ and $28 \%$ respectively. There are in the data shows, that 'never' reading before lockdown is $3 \%$ and during lockdown $10 \%$ it increased because of COVID19.

Frequency of reading newspapers \& books

Table 7: Frequency of reading newspaper before and during lockdown

\begin{tabular}{lcccc}
\hline & \multicolumn{2}{c}{ Before } & \multicolumn{2}{c}{ During } \\
& Freq & $\%$ & Freq & $\%$ \\
\hline Everyday & 15 & 52 & 13 & 45 \\
Sometime & 09 & 31 & 08 & 28 \\
s & & & & \\
Rarely & 04 & 14 & 05 & 17 \\
Never & 01 & 3 & 03 & 10 \\
Total & $\mathbf{2 9}$ & 100 & $\mathbf{2 9}$ & 100 \\
\hline
\end{tabular}

In table 8 presents that, which type of books reading during the lockdown. The range of mean value from 2.40 to 0.20 , the highest priority is given for 'reference books', followed by 'other types of books'. The least priority has given by the respondent for the 'textbooks'.

Table 8: Types of books read during lockdown

\begin{tabular}{lccc}
\hline Types Books & N & Mean & Priority \\
\hline Ref. books & 29 & 2.4 & 1 \\
Others & 29 & 1.4 & 2 \\
Novel & 29 & 0.8 & 3 \\
Books on GK/ & 29 & 0.4 & 4 \\
Textbooks & 29 & 0.2 & 5 \\
\hline
\end{tabular}

Style of reading

Styles of reading are given in table 9, i.e. quick browsing, in-depth reading, note-making, and others. This table shows that, most of the respondents $(48 \%)$ style of reading for 'indepth reading', followed that, 'quick browsing' (28\%), and for 'note-making (17\%). Only 3\% reading style is for 'others'.

Table 9: Style of Reading

\begin{tabular}{lcc}
\multicolumn{1}{c}{ Variables } & $\begin{array}{c}\text { Frequenc } \\
\text { y }\end{array}$ & $\begin{array}{c}\text { Percentag } \\
\text { e }\end{array}$ \\
\hline $\begin{array}{l}\text { Quick } \\
\text { Browsing }\end{array}$ & 08 & 28 \\
\hline In depth & 14 & 48 \\
\hline
\end{tabular}

May, 2020. VOL.12. ISSUE NO. 1 


\begin{tabular}{lcc}
\hline Reading & & \\
\hline Note Making & 05 & 17 \\
\hline Other & 01 & 3 \\
\hline Total & $\mathbf{2 8}$ & $\mathbf{1 0 0}$ \\
\hline
\end{tabular}

Time spent

Time spent on the reading before the lockdown situation. In table 10 indicates that, most of the respondents were spending time reading ' 1 to 3 hours' is $38 \%$, followed that, 'less than 1 hour' is $34 \%$, and ' 3 to 5 hours' time spent for reading is $24 \%$. Only $3 \%$ of respondents spent time for reading ' 5 hours and above'.

Table 10: Time spent for reading before lockdown

\begin{tabular}{lcc}
\hline \multicolumn{1}{c}{ Time spent } & $\begin{array}{c}\text { Frequenc } \\
\mathbf{y}\end{array}$ & $\%$ \\
\hline Less than 1 Hour & 10 & 34 \\
\hline 1 to 3 Hours & 11 & 38 \\
\hline 3 to 5 Hours & 07 & 24 \\
\hline $\begin{array}{l}5 \text { Hours and } \\
\text { above }\end{array}$ & 01 & 3 \\
\hline Total & $\mathbf{2 9}$ & $\mathbf{1 0 0}$ \\
\hline
\end{tabular}

Table 11 and chart no.2 shows that the teaching members were asked how many hours per day spend time for reading, time group ' 5 hours and above' that is $4 \%$ for books. A majority of respondents spent the time in ' 3 to 5 hours', $25 \%$ time spent on books, followed by electronic media is $15 \%$ time spent. A total of $46 \%$ time spend tin ' 1 to 3 hours', followed that $39 \%$ time spent on electronic sources. Around 'less than 1 hour' $90 \%$ spend the time for newspapers, followed that $80 \%$ time for magazines, $71 \%$ time spend for journals, $46 \%$ time spend for electronic media and very less $25 \%$ time spend for books.

\begin{tabular}{|c|c|c|c|c|}
\hline $\begin{array}{l}\text { Reading } \\
\text { Materials }\end{array}$ & $\begin{array}{l}\text { Less } \\
\text { than1 }\end{array}$ & $\begin{array}{l}1 \text { to } 3 \\
\text { hours }\end{array}$ & $\begin{array}{l}3 \text { to } 5 \\
\text { hours }\end{array}$ & $\begin{array}{c}5 \\
\text { hours } \\
\text { above }\end{array}$ \\
\hline Books & $\begin{array}{c}07 \\
(25 \%)\end{array}$ & $\begin{array}{c}13 \\
(46 \%)\end{array}$ & $\begin{array}{c}07 \\
(25 \%)\end{array}$ & $\begin{array}{c}01 \\
(4 \%)\end{array}$ \\
\hline Journals & $\begin{array}{c}12 \\
(71 \%)\end{array}$ & $\begin{array}{c}05 \\
(29 \%)\end{array}$ & - & - \\
\hline $\begin{array}{l}\text { Magazine } \\
\text { S }\end{array}$ & $\begin{array}{c}12 \\
(80 \%)\end{array}$ & $\begin{array}{c}03 \\
(20 \%)\end{array}$ & - & - \\
\hline $\begin{array}{l}\text { Newspap } \\
\text { er }\end{array}$ & $\begin{array}{c}18 \\
(90 \%)\end{array}$ & $\begin{array}{c}02 \\
(10 \%)\end{array}$ & - & - \\
\hline $\begin{array}{l}\text { Electronic } \\
\text { Media }\end{array}$ & $\begin{array}{c}13 \\
(46 \%) \\
\end{array}$ & $\begin{array}{c}11 \\
(39 \%)\end{array}$ & $\begin{array}{c}04 \\
(15 \%)\end{array}$ & - \\
\hline
\end{tabular}

Chart 2: Time spent for reading during lockdown 


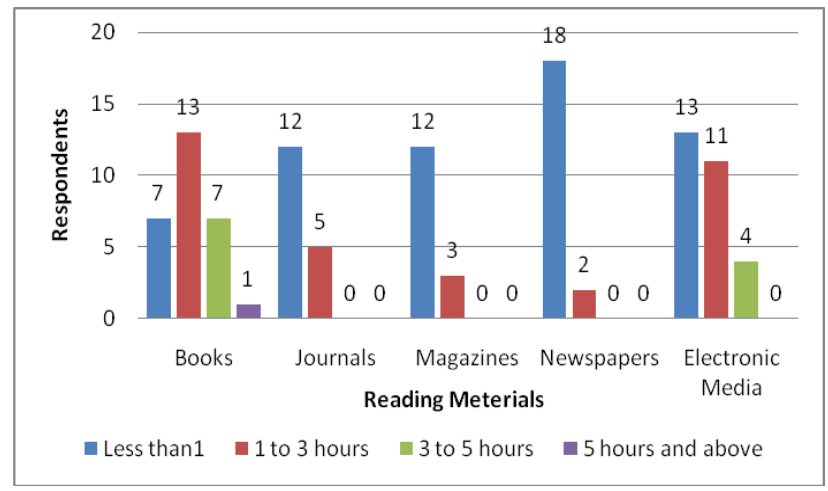

Teaching members were reading electronic sources through different devices like mobile, laptop, PC and other devices. In table 12 showed that the range of mean values from 3.00 to 0.20 . Related to the results, the priority has given to the mobile, followed by a laptop, other devices, and $\mathrm{PC}$ respectively.

Use of devices

Table 12: Device use to read from electronic sources

\begin{tabular}{llcc}
\hline Device & N & Mean & Priority \\
\hline Mobile & 29 & 3.00 & 1 \\
Laptop & 29 & 2.00 & 2 \\
Others & 29 & 0.40 & 3 \\
Tablet & 29 & 0.20 & 4 \\
PC & 29 & 0.20 & 5 \\
\hline
\end{tabular}

Change the performance through reading. In table 13 and chart 3 reveal that a majority of respondents say 'yes' that is $97 \%$, and only 1 respondent says 'no' that is $3 \%$.

\section{Change performance}

Table 13: Reading bought a change the performance

\begin{tabular}{lcc}
\hline Response & Frequency & Percentage \\
\hline Yes & 28 & 97 \\
No & 01 & 3 \\
Total & $\mathbf{2 9}$ & $\mathbf{1 0 0}$ \\
\hline
\end{tabular}

Chart 3: Change the performance through reading

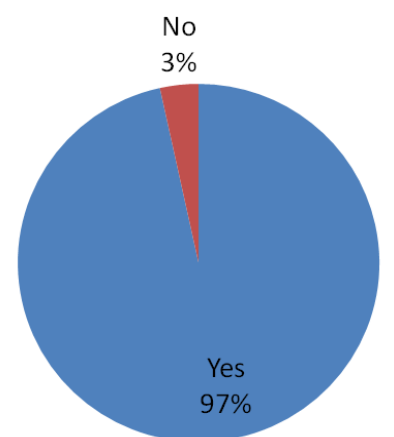

Change of Performance through reading 


\section{Findings}

The study is conducted on reading habits of the academic staff of BAOU. $83 \%$ of the respondents were reading every day during the lockdown. Most of the respondents were using print and electronic both the sources for reading. A majority respondent was given the first priority to seek the information through books. They have also given the top priority given to reference books to update their subject knowledge. In-depth reading and quick browsing were also the styles of reading of academic staff during the lockdown. Maximum respondents were given the priority for accessing electronic information through mobile, followed that laptop. In this study, we found that $97 \%$ of respondents said 'yes' to change the performance through reading.

\section{Conclusion}

We found that the majority of respondents are female faculty members. Reading habits enriches knowledge and wisdom. The impact on the reading habits of the academic staff of BAOU during the lockdown of COVID-19 was analysed. Reading habits and their attitude towards seeking information and update the subject knowledge through reading materials and they spent the time for reading and their reading style also studied in this paper. 
Towards Excellence: An Indexed, Refereed \& Peer Reviewed Journal of Higher Education / Dr. Priyanki Vyas \& Mr. Balvant Tandel/ Page 28-37

\title{
References
}

Annable, J. (2017). Reading habits of adults: What drives the choice to read or not read? New York: Education and Human Development Master's Theses.

Chettri, K., \& Rout, S. (2013). Reading Habits- An overview. Journal of Humanities and Social Science, $14(6), 13-17$.

Dimitrius, J. E. (1999). Reading People: How to understand people and predict their behaviouranytime, anyplace. New York: The Ballantine Publishing Group.

Karim, N. S. (2007). Reading habits and attitude in the digital age: Analysis of gender and academic program differences in Malaysia. The Electronic Library , 25 (3), 287-298.

Mayekar, S. (2010). Study of the impact of reading habits on the performance of UG and PG students. New Delhi: UGC, Minor Research Project.

Mikulecky, L. J., Shanklin, N. L., \& Caverly, D. C. (1979). Adult Reading habits, attitudes and motivations: A cross-sectional study. California: The Educational Resources Information Center (ERIC).

\section{Dr. Priyanki Vyas \\ Associate Professor \\ Dr Babasaheb Ambedkar Open University, Ahmedabad \\ priyanki.vyas@baou.edu.in}

\author{
\& \\ Mr. Balvant Tandel \\ Assistant Professor \\ Anand Institute of P.G. Studies in Arts \\ balvanttandel@gmail.com
}

